of zygosis, ploidy and C-value. In this case, it is impossible to determine each component's specific contribution and molecular analytical tools will necessarily over- or underestimate the nominal GM component of the product ingredient. De facto, the quantification of the GM content in a sample provides us with neither the true molecular dosage of the modification(s) (e.g., the number of modified haploid genomes versus the total number of haploid genomes) nor the content defined on the basis of European regulations; instead, it gives us a relative gene dosage determined with respect to the employed CRM.

Taken together, these problems create an unclear environment in which the regulations are unenforceable using the molecular analytical tools available. Every analytical result could potentially be invalidated by means of scientific data demonstrating that the CRMs used are not representative for the samples under analysis. The EU legislators continue to fudge; the current regulation $1829 / 2003$ (ref. 4) uses the same imprecise 1\% threshold as its predecessor 49/2000 (ref. 2). And the EC's most recent recommendation $(2004 / 787 / 2000)^{17}$ only partly solves the problem by defining the percentage of GM DNA as "the percentage of GM-DNA copy numbers in relation to target taxon specific DNA copy numbers calculated in terms of haploid genomes."

Three years after the current EC regulation ${ }^{4}$ was issued, all the operative structures described within it (that is, the European Food Safety Agency and the Community Reference Laboratory) are now fully active. Yet, only two novel authorizations were granted in 2004 (Bt11 sweet corn and NK603 maize). All the other $25 \mathrm{GM}$ plants, which are listed as authorized in the Community Register of GM Food and Feed (http://europa. eu.int/comm/food/dyna/gm_register/index_ en.cfm), were placed on the market in the EC before the entry into force of the current regulation.

European legislations must move quickly to amend the current regulation so that rules provide an exact and scientifically acceptable definition of GMO content that can be adopted in testing. It is not a question of moving the regulatory goal posts; the current legislation doesn't even tell us where to put the goal posts.

Florian Weighardt

via Milano 1095, 21027 Ispra (VA), Italy. e-mail: florian.weighardt@poste.it
3. The Council of the European Parliament. Off. J. Eur. Commun. L268, 24-28 (2003).

4. The Council of the European Parliament. Off. J. Eur. Commun. L268, 1-23 (2003),

5. The European Parliament and The Council. Off. J. Eur. Commun. L106, 1-38 (2001).

6. The European Parliament and The Council. Off. J. Eur. Commun. L109, 29-42 (2000).

7. Mattarucchi, E., Weighardt, F., Barbati, C., Querci, M. \& Van den Eede, G. Eur. Food Res. Technol. 221, 511-519 (2005).

8. Miraglia, M. et al. Food Chem. Toxicol. 42, 1157-1180 (2004).

9. Trapmann, S., \& Emons, H. Anal. Bioanal. Chem. 381, 72-74 (2005)

10. Trapmann, S. et al. (eds). The Certification of Reference Materials of Dry-mixed Soya Powder with
Different Mass Fractions of Roundup Ready SoyaIRMM-410S. (Office for Official Publications of the European Communities, Luxembourg, 2002).

11. Rayburn, A.L. \& Auger, J.A. Theor. Appl. Genet. 79 470-474 (1990).

12. Rayburn, A.L., Auger, J.A., Benzinger, E.A. \& Hepburn A.G. J. Exp. Bot. 40, 1179-1183 (1989).

13. Bullock, D. \& Rayburn, A. Maydica 36, 247-250 (1991).

14. Biradar, D.P., Bullock, D. \& Rayburn, A. Theor. Appl. Genet. 88, 557-560 (1994).

15. Laurie, D.A. \& Bennett, M.D. Heredity 55, 307-313 (1985).

16. Trifa, Y. \& Zhang, D. J. Agr. Food. Chem. 52, 1044 1048 (2004).

17. The European Commission. Off. J. Eur. Commun. L348 18-26 (2004).

\title{
ATCC not involved in negotiations with India
}

\section{To the editor:}

The American Type Culture Collection (ATCC) would like to clarify statements in an news article by K.S. Jayaraman published in the September issue of Nature Biotechnology $(23,1031,2005)$ entitled "Materials exchange deal meager boost to India's biotech." The article describes midJune discussions between a delegation of US Department of Commerce officials, led by acting deputy secretary David Sampson, and a delegation from India led by science minister Kapil Sibal.

The article suggests the two groups reached agreement on a proposal to govern the transfer of biological material from the United States to India. The proposal seems to mention ATCC specifically: "Under the plan," the article states, "India's Department of Biotechnology would procure biological materials from the American Type Tissue [sic] Collection (ATCC) and warrant against their misuse or subsequent acquisition by bioterrorists, with safeguards and export controls similar to those around nuclear technology."

ATCC would like to notify the scientific community that no ATCC representative was invited to attend the Department of Commerce's meeting with the India delegation and ATCC is not aware of any specific agreement made by the US Federal Government with India or any other country for obtaining biological materials from ATCC. Aside from the fact that an agreement was apparently made without ATCC's involvement, firmly established policies at ATCC block any type of exclusive relationships with individual countries. Furthermore, for decades, and continuing today, Indian scientists registered with our organization have been welcome to order products from ATCC for their research.

The article also mentions that Indian scientists have experienced "problems working with" ATCC. Our records indicate that all orders from registered scientists in India have been successfully filled. ATCC is glad to provide its high-quality research materials to Indian scientists. All of ATCC's rules, shipping policies or pricing schemes are applied to all countries equally. In no way does ATCC restrict access to its collection for registered scientists in India or another country.

\section{Jesus Soriano}

ATCC Vice President for Licensing, Contracts and Compliance, American Type Culture Collection, Contracts, Compliance and Licensing, 10801 University Blvd., Manassas, Virginia 20110,USA.e-mail: jsoriano@atcc.org

1. Tsioumani, E. Rev. Eur. Commun. Int. Environ. Law 13, 279-288 (2004).

2. The European Commission. Off. J. Eur. Commun. L6, 13-14 (2000). 